\title{
KARAKTERISASI SIFAT BIOKIMIA ISOLAT BAKTERI KITINOLITIK ASAL TAMBAK UDANG
}

\section{BIOCHEMICAL CHARACTERIZATION OF CHITINOLITIC BACTERIA FROM SHRIMP FARMS}

\author{
Sri Wahyuni ${ }^{1}$, Mery Wahyuni Kirami ${ }^{2}$, Andi Khaeruni ${ }^{3}$ \\ 1Jurusan Teknologi Pangan Fakultas Pertanian Universitas Halu Oleo \\ 2Jurusan Pendidikan MIPA Universitas Halu Oleo \\ ${ }^{3}$ Jurusan Agroteknologi Fakultas Pertanian Universitas Halu Oleo \\ E-mail : sriwahyuni_aan@yahoo.com
}

Fakultas Pertanian Universitas Halu Oleo

Jl. HEA Mokodompit Anduonohu, Kendari

\begin{abstract}
Abstrak
Informasi tentang sifat-sifat biokimia yang dimiliki oleh suatu isolat bakteri memberi peluang dalam mengungkap potensi isolat untuk pemanfaatan pada berbagai bidang. Penelitian ini bertujuan untuk mengetahui sifat-sifat biokimia dari bakteri kitinolitik isolat SSA2.B4.1 dan SSD2A7.1 yang berasal dari tambak udang di Kabupaten Pinrang dan Maros, Sulawesi Selatan. Penelitian dilakukan dengan uji-uji biokimia terhadap kedua isolat tersebut. Hasil penelitian menunjukkan isolat bakteri SSA2B4.1 berjenis gram positif dan mampu menggunakan berbagai senyawa karbohidrat sebagai sumber karbon, sedangkan SSD2A7.1 berjenis gram negatif dan tidak mampu menggunakan berbagai senyawa karbohidrat sebagai sumber karbon. Isolat bakteri SSA2.B4.1 selain mampu mensekresi enzim kitinase, juga mampu mensekresi enzim selulase dan protease, sehingga berpotensi untuk diaplikasikan pada bidang industri deterjen, proses deproteinasi dalam pembuatan kitin serta sebagai agen hayati patogen tanaman.
\end{abstract}

Kata kunci : bakteri kitinolitik, limbah kulit udang, sifat biokimia

\begin{abstract}
The biochemistry characteristics information possessed by a bacterial isolate offered the chance to reveal their potentials to usage in multiple fields. The purpose of this research was to find the characteristics of biochemical properties from isolate chitinolitic bacterial SSA2.B4.1 and SSD2A7.1 isolated from shrimp farms in Pinrang and Maros, South Sulawesi. The research was conducted with biochemical test for both of the isolates. The results showed that bacterial isolate SSA2B4.1 was categorized as positive Gram bacteria and was able to use multiple types of carbohydrates compound as carbon source, while SSD2A7.1 was categorized as negative Gram bacteria and couldn't use any kind of carbohydrate compound as carbon source. The SSA2.B4.1 isolate, other than able to excrete chitinase enzyme, was also able to excrete cellulose and protease enzymes that was potentially applied in the detergent industries, deproteination process in chitin creation as well as in agriculture field as biological agent to control plant pathogens.
\end{abstract}

Keyword : Biochemical characters, chitinolitic bacteria, shrimp shell waste,

\section{PENDAHULUAN}

Sebagai negara dengan biodiversitas tinggi, Indonesia memiliki sumber isolat mikroba yang bernilai ekonomis karena berpotensi digunakan dalam industri, khususnya industri yang berbasis enzim (Suryanto et al., 2006). Mikroba penghasil kitinase merupakan salah satu kelompok mikroba yang bernilai ekonomis karena kemampuannya menghidrolisis kitin menjadi derivat kitin yang banyak dimanfaatkan di bidang pertanian, kesehatan, pengelolaan limbah, dan teknologi pangan (Sudhakar dan $\mathrm{Na}$ - garajan, 2010; Eurich et. al., 2009). Diyakini mikroba penghasil kitinase tersebar di alam Indonesia karena sebagai negara maritim ketersediaan substrat kitin dari limbah hasil perikanan, seperti kepiting dan udang cukup melimpah.

Bakteri kitinolitik merupakan salah satu mikroba penghasil kitinase yang mengkonversi kitin menjadi monomer atau oligomernya. Bakteri kitinolitik memanfaatkan kitinase untuk asimilasi kitin sebagai sumber karbon dan nitrogen (Gohel et. al., 2006; Kamil et. al., 2007). Bakteri 
penghasil kitinase yang telah dilaporkan diantaranya Bacillus spp. (Bal et. al.,2009), Bacillus subtilis (Senol et. al, 2014), B. Licheniformis (Abirami et. al, 2012), Pseudomonas fluorescens (Nandakumar, 2007), Sanguibacter sp. (Yoong et. al., 2005), Aeromonas punctata (Saima et. al., 2013) dan Sterptomyces sp. (Kim et. al., 2003).

Wahyuni et al., (2008) telah melaporkan 28 isolat bakteri penghasil kitinase yang diisolasi dari tam-bak udang, penampungan udang, limbah pengo-lahan udang, dan tempat pembuangan limbah pa-dat udang di beberapa lokasi industri perikanan di Sulawesi Selatan dan Sulawesi Tenggara. Hasil skrining lebih lanjut diperoleh dua isolat yaitu SSA2.B4.1 dan SSD2A7.1 yang berasal dari tambak udang mampu tumbuh pada suhu $37^{\circ} \mathrm{C}$ dengan aktivitas enzim kitinase yang tinggi masing-masing sebesar 0,452 Unit/ml enzim dan 0,449 Unit/ml enzim. Enzim tersebut memiliki $\mathrm{pH}$ optimum 4-6 dan suhu optimum $70^{\circ} \mathrm{C}$, sehingga berpotensi dikembangkan sebagai enzim termostabil.

Identifikasi bakteri berdasarkan sifat-sifat biokimia penting untuk mendapatkan informasi yang lebih banyak tentang peluang kedua isolat tersebut untuk dikembangkan sebagai sumber enzim termostabil khususnya untuk keperluan aplikasi di bidang pangan, industri, dan pertanian. Berdasarkan hal tersebut, maka sebagai langkah awal perlu dilakukan karakterisasi sifat biokimia dari bakteri kitinolitik isolat SSA2.B4.1 dan SSD2A7.1.

\section{BAHAN dan METODE}

Bahan utama yang digunakan pada penelitian ini adalah bakteri kitinolitik isolat SSA2.B4.1 dan SSD2A7.1 (Gambar 1, Wahyuni et. al. 2008,), medium trypticase soy agar (TSA), medium Luria Agar (LA), medium Nutrien Agar (NA), etanol, karboksimetilselulosa (CMC), brom timol biru (BTB), akuades dan berbagai bahan kimia lainnya yang digunakan dalam pengujian karakterisasi sifat bio-kimia.

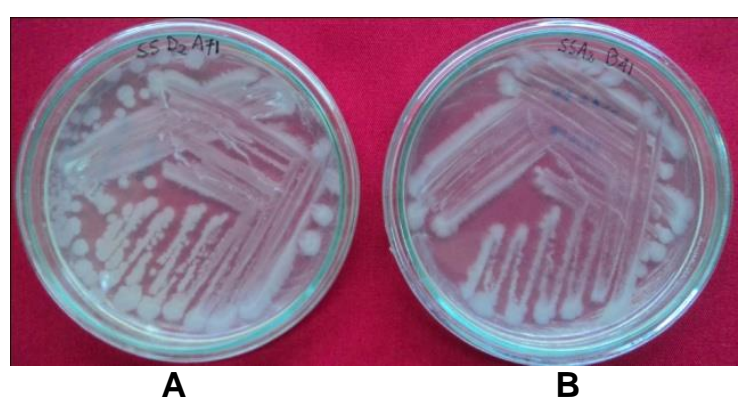

Gambar 1. Isolat bakteri kitinoloitik (A) SSD2A7.1 dan (B) SSA2.B4.1

\section{Penyegaran dan Pemurnian Isolat Bakteri} Uji.

Isolat SSA2.B4.1 dan SSD2A7.1 digoreskan secara terpisah pada médium TSA dan diinkubasi selama 2 hari pada suhu kamar dalam inkubator. Kultur murni dari kedua isolat tersebut dibiakkan secara terpisah pada médium yang sama untuk digunakan sebagai inokulum uji dalam tahap karakterisasi biokimia yang meliputi :

\section{Pengujian Gram}

Reaksi Gram ditentukan berdasarkan metode pewarnaan Gram seperti yang dikemukakan oleh Lay (1994). Setelah dilakukan pewarnaan Gram, preparat diamati dengan mikroskop, untuk melihat bentuk sel dan reaksi Gram. Bakteri Gram positif tampak berwarna biru keunguan sedangkan Gram negatif berwarna merah muda.

\section{Uji Pembentukan Asam (Karbohidrat sebagai Sumber karbon).}

Pengujian ini dilakukan berdasarkan metode yang dikemukakan oleh Lay (1994). Senyawa karbohidrat $10 \%$ berupa glukosa, sukrosa, laktosa, maltosa, dan manitol, disterilisasi secara terpisah dari medium. Medium dalam tabung reaksi masing-masing ditambahkan senyawa karbohidrat 1\%, se-bagai indikator diberi brom timol biru (BTB). Satu ose biakan murni isolat bakteri secara terpisah diinokulasi ke dalam biakan kaldu karbohidrat, lalu diinkubasi dalam inkubator pada suhu $30^{\circ} \mathrm{C}$ selama beberapa 7 hari. Pemanfaatan karbohidrat sebagai sumber karbon ditandai dengan pembentukan asam yang ditunjukkan dengan perubahan warna medium dari hijau menjadi kuning.

\section{Uji Methyl Red.}

Sebanyak $5 \mathrm{~mL}$ kaldu MR-VP dimasukkan dalam tabung reaksi, lalu diinokulasikan satu ose inoku-lum isolat bakteri uji (umur 2 hari). Tabung diinkubasi pada suhu $37^{\circ} \mathrm{C}$ selama 48 jam. Setelah itu ditambahkan 5 tetes reagen methyl red. Jika kaldu berwarna merah menunjukan hasil uji positif, jika kaldu berwarna kuning maka hasil uji negatif (Lay, 1994).

\section{Uji Voges Proskauer}

Kaldu MR-VP sebanyak $5 \mathrm{~mL}$ dimasukkan ke dalam tabung reaksi, diinokulasi bakteri pada kaldu MR-VP, kemudian diinkubasi pada suhu $37^{\circ} \mathrm{C}$ selama 24 jam. Setelah itu ditambahkan 10 tetes larutan $\mathrm{KOH} 40 \%$ dan 15 tetes larutan a-naftol, di-kocok dan dibiarkan 30 menit. Uji positif jika kaldu berwarna merah dan uji negatif jika kaldu tidak me-ngalami perubahan warna setelah penambahan reagen (Lay, 1994). 


\section{Uji Oksidase}

Isolat bakteri uji ditumbuhkan pada media Nutrien Agar (NA), diinkubasi pada suhu $30^{\circ} \mathrm{C}$ selama 24 jam, kemudian ditambahkan reagen uji oksidase (campuran 1:1 larutan $\alpha$-naftol 1\% dan $1 \%$ larutan dimetil-p-fenilendiamin oksalat) pada koloni bakteri dan didiamkan selama 30 menit. Uji positif jika warna koloni berubah menjadi hitam (Lay, 1994).

\section{Uji Katalase}

Isolat bakteri uji ditumbuhkan pada media NA dan diinkubasi selama 24 jam pada suhu $30^{\circ} \mathrm{C}$, kemudian ditambahkan reagen $\mathrm{H}_{2} \mathrm{O}_{2}$ $3 \%$. Terjadinya gelembung udara pada biakan menunjukkan bahwa isolate baktei uji mereduksi $\mathrm{H}_{2} \mathrm{O}_{2}$ (Lay, 1994).

\section{Uji Indol}

Medium tripton cair dimasukkan ke dalam tabung reaksi sebanyak $5 \mathrm{ml}$, diinkubasi selama 24 jam pada suhu $35^{\circ} \mathrm{C}$, kemudian ditambahkan beberapa tetes reagen Kovacs. Jika terbentuk warna merah dipermukaan medium menunjukkan hasil uji positif (Waluyo, 2008).

\section{Uji Sitrat}

Isolat bakteri uji diinokulasi pada media Simmon sitrat agar dengan inokulum yang tipis, kemudian diinkubasi pada suhu $35^{\circ} \mathrm{C}$ selama 48 jam. Jika terjadi perubahan warna dari hijau menjadi biru menunjukan uji positif (Lay, 1994).

\section{Uji Pencairan Gelatin}

Isolat bakteri uji diinokulasi pada media dengan cara menusukkan mikroba yang akan diujikan se-dalam $3 / 4$ bagian dari lapisan permukaan, kemudian diinkubasi pada suhu $35^{\circ} \mathrm{C}$ selama 24 jam. Jika media gelatin mencair, maka langkah selanjutnya dimasukkan dalam lemari es selama 30 menit. Diamati pencairan gelatin, jika terdapat gelatin yang mencair menunjukkan uji positif. Namun jika tidak mencair maka diinkubasi kembali selama 1 minggu pada suhu $35^{\circ} \mathrm{C}$. Uji dianggap negatif jika setelah satu minggu gelatin tidak mencair sedikitpun (Lay, 1994).

\section{Uji Hidrogen Sulfida ( $\mathrm{H}_{2} \mathrm{~S}$ )}

Isolat bakteri uji dibiakkan pada tabung reaksi yang telah berisi media TSIA $7 \mathrm{~mL}$ dengan cara menusukkan jarum ose ke dalam media kemudian baru diinokulasi pada bagian slant TSIA. Inkubasi pada suhu $37^{\circ} \mathrm{C}$ selama 24 jam. Diamati pertumbuhannya pada bagian Butt dan Slant (Lay, 1994).

\section{Uji Urease}

Biakan bakteri uji diinokulasi pada media urea agar miring, kemudian diinkubasi pad suhu $35^{\circ} \mathrm{C}$ selama 24 jam. Jika terjadi perubahan warna dari kuning menjadi merah keunguan maka menunjukkan uji positif (Hadioetomo, 1985).

\section{Uji Reduksi Nitrat}

Uji nitrat dilakukan dengan menumbuhkan bakteri uji pada medium nitrat dalam tabung reaksi yang telah dilengkapi dengan tabung Durham, kemudian diinkubasi pada suhu $35^{\circ} \mathrm{C}$ selama 74 jam, kemudian ditambahkan $1 \mathrm{ml}$ reagen nitrat dan diinkubasi selama 24 jam pada suhu ruangan. Terjadinya perubahan warna media menjadi merah atau merah muda menunjukkan bahwa bakteri uji dapat mereduksi nitrat (Lay, 1994).

\section{Uji Selulase}

Sebanyak $100 \mu \mathrm{L}$ Suspensi bakteri uji diinokulasikan dalam lubang yang dibuat di media LA yang mengandung CMC pada cawan Petri, kemudian diinkubasi dalam incubator selama 24 jam pada suhu $37^{\circ} \mathrm{C}$. Uji positif ditunjukkan dengan terbentuknya zona bening di sekitar daerah inokulasi (Meryandini et al., 2009).

\section{Uji Protease}

Biakan bakteri uji diinokulasi pada media LA yang mengandung susu skim pada cawan petri ke-mudian diinkubasi selama 24 jam dalam inkubator pada suhu $37^{\circ} \mathrm{C}$. Uji positif ditunjukkan dengan terbentuknya zona bening di sekitar daerah goresan (Akhdiya, 2003).

\section{Uji Hidrolisis Pati}

Sebanyak $100 \mu \mathrm{l}$ suspensi bakteri uji diinokulasi pada lubang di media NA yang mengandung pati, kemudian diinkubasi selama 24 jam dalam inkubator pada suhu $37^{\circ} \mathrm{C}$. Uji positif ditunjukkan dengan terbentukknya zona bening di sekitar daerah inokulasi (Hastuti et al., 2012).

\section{HASIL dan PEMBAHASAN}

Hasil uji sifat biokimia menunjukkan bahwa bakteri kitinolitik isolat SSA2.B4.1 dan SSD2A7.1 memiliki sifat-sifat biokimia yang berbeda dalam reaksi Gram, kemampuan memanfaatkaan karbohidrat sebagai sumber karbon, uji oksidase, uji indol, uji sitrat, dan kemampuan menghidrolisis selulosa (Tabel 1)

Isolat SSA2.B4.1 merupakan bakteri Gram positif, sedangkan isolat SSD2A7.1 adalah bakteri Gram negatif. Penyebab perbedaan reaksi Gram disebabkan adanya perbedaan struktur dan komposisi dinding sel bakteri Gram positif dan Gram negatif. Bakteri Gram negatif mengandung lipid dalam persentase lebih tinggi dibanding yang dikandung bakteri Gram positif. Dinding sel bakteri Gram negatif mempunyai dinding sel yang lebih tipis dan kandungan peptidoglikan jauh lebih sedikit dibanding din- 
ding sel bakteri Gram positif. Tipisnya lapisan peptodoglikan pada Gram negatif memungkinkan terjadinya ekstraksi kompleks kristal violet-iodium. Sedangkan lapisan peptidoglikan yang lebih tebal pada Gram positif menyebabkan pemberian larutan pemucat (alkohol) akan mengurangi diameter pori-pori pada lapisan peptidoglikan dan menyebabkan kompleks kristal violet-iodin terperangkap di dalam dinding sel bakteri.

Tabel 1. Sifat sifat biokimia isolat SSA2B4.1 dan SSD2A7.1.

\begin{tabular}{lcc}
\hline \multicolumn{1}{c}{ Sifat-sifat yang diuji } & $\begin{array}{c}\text { Isolat } \\
\text { SSA2B4.1 }\end{array}$ & $\begin{array}{c}\text { Isolat } \\
\text { SSD2A7.1 }\end{array}$ \\
\hline Reaksi Gram & + & - \\
Pemanfaatan Sumber & & \\
Karbon & + & - \\
$\quad$ Glukosa & + & - \\
$\quad$ Manitol & + & - \\
$\quad$ Sukrosa & + & - \\
$\quad$ Maktosa & + & - \\
Metyl Red & - & - \\
Voges Proskauer & - & - \\
Katalase & + & + \\
Oksidase & + & - \\
Indol & + & - \\
Sitrat & - & + \\
Pencairan Gelatin & - & - \\
Hidrogen Sulfida & - & - \\
Urease & - & - \\
Reduksi Nitrat & - & + \\
Selulase & + & - \\
Protease & + & + \\
Hidrolisis pati & + & - \\
\hline Keterangan = +, bereaksi positif; &,- bereaksi negatif
\end{tabular}

Isolat SSA2.B4.1 mampu membentuk asam pada médium yang mengandung senyawa glukosa, manitol, sukrosa, laktosa, dan maltosa, berarti isolat tersebut mampu menggunakannya sebagai sumber karbon, sebaliknya isolat SSD2A7.1 tidak mampu menggunakan kelima senyawa karbohidrat tersebut sebagai sumber karbon, sehingga sumber karbon isolat SSA2.B4.1 lebih luas dibanding isolat SSD2.A7.1. Pada Pengujian Metyl Red dan Voges Proskauer, pencairan gelatin, hidrogen sulfida, urase, dan hidrolisis pati kedua isolat bakteri yang diuji bereaksi negatif.

Kedua isolat yang diuji bereaksi positif pada uji katalase yang dibuktikan dengan timbulnya gelembung-gelembung udara dari campuran koIoni bakteri dengan $\mathrm{H}_{2} \mathrm{O}_{2} 3 \%$. Timbulnya gelembung-gelembung udara pada uji katalase membuktikan bahwa bakteri menghasilkan enzim katalase sehingga mampu mengubah hidrogen peroksida menjadi air dan oksigen (Lay, 1994). Uji oksidase pada isolat bakteri SSD2A7.1, memberikan hasil uji negatif karena tidak terbentuk warna hitam pada koloni bakteri, sedangkan uji oksidase pada isolat bakteri SSA2B4.1 memberikan hasil uji positif yang ditandai dengan terbentuknya warna hitam pada koloni bakteri. Perubahan warna ini mengindikasikan adanya enzim sitokrom oksidase yang dimiliki oleh isolat bakteri SSA2B4.1 yang dapat mengoksidasikan larutan reagen uji oksidase.

Reaksi positif ditunjukkan isolat SSA2B4.1 pada uji indol, sedangkan isolat SSD2A7.1 bereaksi negatif. Reaksi postif pada uji indol ditandai dengan terbentuknya lapisan merah pada permukaan media setelah ditetesi reagen kovacs. Reaksi positif pada isolat SSA2B4.1 membuktikan bahwa isolat tersebut mampu menghasilkan enzim triptofan untuk memecah asam amino triptofan menjadi indol serta asam piruvat dan $\mathrm{NH}^{+}$(Lay, 1994).

Pada uji sitrat, isolat bakteri SSD2A7.1 tidak menggunakan karbohidarat sebagai sumber karbon dan energi tetapi menggunakan sitrat. Penggunaan sitrat oleh isolat bakteri SSD2A7.1 sebagai sumber karbon dan energi ditunjukkan dengan perubahan warna media biakan SCA menjadi biru yang dise-babkan penggunaan sitrat oleh bakteri sehingga asam hilang dari media biakan dan bila sitrat dapat digunakan oleh bakteri maka amonium dihidrogen fosfat turut teruraikan dan akan melepaskan ion amonium $\left(\mathrm{NH}_{4}{ }^{+}\right)$sehingga menyebabkan medium menjadi alkalis, dan indikator brom timol biru berubah dari hijau menjadi biru (Gupte, 1990). Wa-laupun sitrat dapat digunakan oleh bakteri sebagai sumber karbon dan energinya, namun berdasar-kan hasil uji sitrat terhadap isolat bakteri SSA2B4.1 yang memberikan hasil uji negatif, menunjukkan isolat bakteri SSA2B4.1 tidak menggunakan sitrat sebagai sumber karbon dan energinya, tetapi cenderung menggunakan karbohidrat seperti glukosa, sukrosa, laktosa, maltosa, manitol dan selulosa.

Selain dapat memanfaatkan karbohidrat jenis glukosa, sukrosa, laktosa, maltosa dan manitol, isolat bakteri SSA2B4.1 juga dapat menghasilkan enzim selulase dan protease, yang ditandai dengan dengan terbentuknya zona bening di sekitar daerah pertumbuhan bakteri. Enzim selulase dapat menguraikan polisakarida jenis selulosa menjadi unit-unit glukosa, sedangkan pada uji protease, protein diurai menjadi peptida dan asam-asam amino penyusun protein dengan bantuan enzim protease atau peptidase. Berdasarkan cara pemotongan ikatan peptida, enzim peptidase dapat dibagi menjadi eksopeptidase dan endopeptidase yang bekerja secara bersama-sama dalam memotong ikatan peptida pada suatu molekul protein (Mubarik et al., 2000). Eksopeptidase bekerja pada kedua ujung molekul protein, yang terdiri dari dua jenis enzim yaitu karboksipeptidase dan amino peptidase (Naiola et al., 2007). 
Kedua isolat bakteri memberikan hasil uji negatif pada uji hidrolisis pati. Keberadaan pati/amilum yang belum terhidrolisis dalam media biakan ditunjukkan dengan tidak terbentuknya zona bening di sekitar daerah pertumbuhan bakteri dan terbentuknya warna biru kehitaman di sekitar pertumbuhan bakteri setelah diberi beberapa tetes larutan iodium. Hal ini memberikan informasi bahwa kedua isolat bakteri tersebut tidak dapat menghasilkan enzim $\alpha$ amilase yang dapat menghidrolisis pati/amilum menjadi sakarida yang lebih sederhana lagi seperti maltosa dan glukosa.

Berdasarkan hasil uji sifat biokimia dari isolat bakteri SSD2A7.1 memberikan informasi bahwa dalam pengaplikasian isolat bakteri SSD2A7.1 tidak perlu menggunakan karbohidrat (jenis glukosa, sukrosa, laktosa, maltosa dan manitol), selulosa, pati/amilum, gelatin, triptofan, sistein, metionin dan urea pada medium yang digunakan karena substrat-substrat tersebut tidak digunakan oleh isolat bakteri SSD2A7.1 sebagai sumber energi dalam proses metabolismenya. Namun dalam pengaplikasian isolat bakteri SSD2A7.1 dapat digunakan sitrat, dan protein pada medium yang digunakan.

Pada penelitian ini belum dapat diketahui secara pasti genus dari kedua isolat bakteri kitinolitik yang diuji karena masih membutuhkan uji-uji karakterisasi genus. Menurut Holt et al. (1994) ciri-ciri isolat bakteri SSA2B4.1 cenderung mengarah pada ciri-ciri grup 15 (bakteri Gram positif, pembentuk endo-spora) yaitu Bacillus, sedangkan isolat SSD2A7.1 tersebut, cenderung mengarah pada ciri-ciri bakteri yang tergolong famili Pseudomonas.

Isolat bakteri SSD2A7.1 dan SSA2B4.1 berpotensi untuk diaplikasikan pada bidang industri deterjen atau sejenis bahan pembersih lainnya. Deterjen dapat menghilangkan noda atau pengotor yang berupa bahan yang larut dalam minyak atau lemak serta noda atau pengotor yang larut dalam air, namun sulit untuk menghilangkan noda atau pengotor yang tergolong protein sehingga dengan penambahan enzim protease pada deterjen akan menambah daya kerja pembersih dari deterjen tersebut. Enzim protease yang dapat dihasilkan oleh kedua isolat bakteri tersebut juga berpotensi untuk diaplikasikan pada proses deproteinasi dalam pembuatan kitin, selain dapat menghemat biaya produksi, juga relatif lebih ramah lingkungan. Di bidang pertanian isolat SSA2B4.1 berpotensi digunakan untuk mengendalikan cendawan patogen tanaman secara hayati, karena kemampuannya dalam menghasilkan enzim kitinase, sellulase, dan proteinase. Enzim kitinase yang disekresikan oleh bakteri kitinolitik mampu mendegradasi dinding sel cendawan patogen yang menginfeksi pada daerah akar tanaman sehingga perkembangan patogen terganggu (Suryanto et. al, 2006, 2011; Gohel et. al., 2006; Khaeruni et al., 2010, 2012; Senol et. al., 2014). Pada penelitian lain dijelaskan bahwa isolat bakteri penghasil selulosa mampu menghambat perkembangan cendawan Phytophthora capsici secara in-vitro, sehingga berpotensi sebagai agen pengendali hayati penyakit busuk batang pada tanaman lada (Khaeruni et al., 2011).

\section{SIMPULAN}

Isolat SSA2B4.1 merupakan bakteri gram positif yang berbentuk batang, mampu menggunakan senyawa karbohidrat glukosa, manito, sukrosa, laktosa, dan maltose sebagai sumber karbon, bereaksi positif terhadap uji katalase, oksidase, indol, mampu mereduksi nitrat, menghasilkan enzim selulase dan protease sehingga memiliki sifat-sifat seperti bakteri genus Bacillus sp., sedangkan isolat SSD2A7.1 merupakan bakteri gram negatif berbentuk batang, tidak mampu menggunakan glukosa, manito, sukrosa, laktosa, dan maltose sebagai sumber karbon, namun menggunakan sitrat, mampu mereduksi nitrat, sehingga memiliki sifat-sifat seperti genus Pseudomonas sp.

\section{DAFTAR PUSTAKA}

Abirami, S., Ronald, J., Kannan M., and AJA, R.S. 2012. Bioconversion of Shrimp Shell Waste by Bacillus Licheniformis for the Production of Antifungal Chitinase Enzyme. Research J. of Pharmaceutical, Biological and Chemical Sciences. 3(4): 789-796.

Akhdiya, A., 2003. Isolasi Bakteri Penghasil Enzim Protease Alkalin Termostabil. Buletin Plasma Nutfah. 9(2): 38-44

Bal, S., Mishra, R.R., Rath, B., Sahu, H.K., and Thatoi, H.N. 2009. Characterization and extracellular enzyme activity of predominant marine Bacillus spp. isolated from sea water of Orissa Coast, India. Malaysian J. of Microbiology, Vol 5(2) : 8793

Eurich, K., Segawa, M., Toei-Shimizu, S., Mizoguchi, E. 2009. Potential role of chitinase 3-like-1 in inflammation associated carcino-genic changes of epithelial cells. World J. Gastroenterol. 15 (42) : $5249-5259$.

Gupte, S. 1990. Mikrobiologi Dasar. Binarupa Ak-sara. Jakarta.

Gohel, V., Singh, A., Vimal, M., Ashwini, P., and Chhatpar, H.S. $2006 . \quad$ Review. Bioprospecting and antifungal potential 
Chitinolytic micro-organisms. African J. of Biotechnology 5(2):54-72.

Hadioetomo, R.S. 1985 . Mikrobiologi Dasar dalam Praktek Teknik dan Prosedur Dasar Labo-ratorium. Gramedia. Jakarta.

Hastuti, W., Agustien, A., dan Nurmiati. 2012. Penapisan dan Karakterisasi Bakteri Amilo-Termofilik dari Sumber Air Panas Semurup, Kerinci, Jambi. Jurnal Biologi Universitas Andalas. 1(2) : 150-155.

Holt, J.G., Kriegm N.R., Sneath, P.H.A., Staley, J.T., Williams, S.T. 1994. Bergey's Manual of Determinative Bacteriology .Edisi kesembilan. Williams \& Wilkins. Baltimore, Maryland.

Kamil, Z., Rizk, M., Saleh, M. and Moustafa, S. 2007. Isolation and identification of rhizosphere soil chitinolytic bacteria and their potential in antifungal biocontrol. Global J. Of Molecular Sciences 2(2): 5766.

Kim, K.J, Yang, Y.J., and Kim, J.G. 2003. Purification and Characterization of Chitinase from Streptomyces sp. M-20. J. of Biochemistry and Molecular Biology, 36 (2): 185-189.

Khaeruni, A., Sutariati, G.A.K, dan Wahyuni, S. 2010. Karakterisasi Dan Uji Aktivitas Bakteri Rizosfer Lahan Ultisol Sebagai Pemacu Pertumbuhan Dan Agensia Hayati Cendawan Pathogen Tular Tanah Secara In-Vitro. J. Hama dan Penyakit Tumbuhan Tropika. 10(2):123-130.

Khaeruni, A., Satrah, V.N., dan Mariadi. 2011 Isolasi, karakterisasi dan uji antagonis bakteri selulolitik terhadap Phytophthora capsici asal tanaman lada (Piper nigrum L.) secara in-vitro. Jurnal Agroteknos. 1(3):156-162

Khaeruni, A. dan Rahman, A. 2012. Penggunaan Bakteri Kitinolitik sebagai Agens Biokontrol Penyakit Busuk Batang oleh Rhizoctonia solani pada Tanaman Kedelai. J. Fitopatologi Indonesia. 8(2):3743

Lay, B.W. 1994. Analisis Mikroba di Laboratorium. Rajawali Press. Jakarta.

Mubarik, N.R., Suwanto, A., dan Suhartono, M.T. 2000. Isolasi dan Karakterisasi Protease Ektraseluler dari Isolat Bakteri Termofilik Ekstrim. Prosiding Seminar Nasional Industri Enzim dan Bioteknologi II. Mikrobiologi, Enzim dan Bioteknologi dalam Perspektif Ekonomi dan Industri. Badan Pengkajian dan Penerapan Teknologi, Jakarta. www.iptek.net.id. (Diakses tanggal 24 Januari 2009).

Meryandini, A., Widosari, W., Maranatha, B., Sunarti, T.C., Rachmania, N., dan Satria, H. 2009. Isolasi Bakteri Selulolitik dan
Karakterisasi Enzimnya. Makara Sains, 13(1): 33-38

Naiola, E., dan Nunuk, W. 2007. Semipurifikasi dan Karakterisasi Enzim Protease Bacillus sp. Jurnal Hayati. 13:51-56.

Nandakumar R., Babu, S., Raguchander, T,, and Samiyappan, R.. 2007. Chitinolytic Activity of Native Pseudomonas fluorescens Strains. J. Agric. Sci. Technol. 9: $61-68$

Saima, Kuddus M., Roohi, Ahmad, I.Z. 2013. Isolation of novel chitinolytic bacteria and production optimization of extracellular chitinase. J. of Genetic Engineering and Biotechnology. 11 : 39-46.

Senol, M., Nadaroglu, H., Dikbas, N., and Kotan, R. 2014. Purification of Chitinase enzymes from Bacillus subtilis bacteria TV125 , investigation of kinetic properties and antifungal activity against Fusarium culmorum. Annals of Clinical Microbiology and Antimicrobials 13:35.

Sudhakar, P., and.Nagarajan, P. 2010. Production of Chitinase by Solid State Fermentation from Rice Bran. International J. of Environmental Science and Development. 1 (5): 435-440.

Suryanto, D dan Munir E. 2006. Potensi Pemanfaatan Isolat Bakteri Kitinolitik Lokal untuk Pengendalian Hayati Jamur. Prosiding Seminar Hasil-Hasil Penelitian Universitas Sumatra Utara. www.usu.ac.id. (Diakses tanggal 23 Januari 2009).

Suryanto, D., Irawati, N., and Munir, E. 2011. Isolation and Characterization of Chitinolytic Bacteria and Their Potential to Inhibit Plant Pathogenic Fungi. Microbiology Indonesia, 5 (3): 144-148

Wahyuni, S., Maggy, T.S., dan Bambang, P.P. 2008. Skrining Bakteri Penghasil Kitinase dari Limbah Udang dan Karakterisasi Enzim Kitinase untuk Produksi dan Aplikasi Oligomer Kitin sebagai Imunostimulan dan Anti Kanker. Laporan Hasil Penelitian Program Intensif Riset Dasar. Lembaga Penelitian Universitas Haluoleo. Kendari.

Waluyo, L. 2008. Teknik dan Metode Dasar dalam Mikrobiologi. Universitas Muhammadiyah Malang Press. Malang.

Yurnaliza, S, Margino., dan Sembiring, L. 2011. Kemampuan Kitinase Streptomyces RKt5 sebagai Antijamur terhadap Patogen Fusarium oxysporum. Jurnal Natur Indonesia 14(1), : 42-46.

Yoong, T., Hong, J., Zhangfu, L., Li, Z., Xiuqiong, D., Ke, T., Shaorong, G., Shigui, L. 2005. Purification and characterization of an extracellular chitinase produced by bacterium C4. Annals of Microbiology 55(3): 213-218. 